\title{
DELIMITATION OF NODAL REGIONS BASED ON TRANSPORT FLOWS: CASE STUDY OF THE CZECH REPUBLIC
}

\author{
Stanislav Kraft ${ }^{1}$, Miroslav Marada ${ }^{2}$, Dagmar Popjaková ${ }^{1}$ \\ ${ }^{1}$ Department of Geography, University of South Bohemia in České Budějovice, Czech Republic \\ ${ }^{2}$ Department of Social Geography and Regional Development, Charles University in Prague, Czech Republic
}

Manuscript received: June 1, 2013

Revised version: February 20, 2014

Kraft S., Marada M., Popjaková D., 2014. Delimitation of nodal regions based on transport flows: Case study of the Czech Republic. Quaestiones Geographicae 33(2), Bogucki Wydawnictwo Naukowe, Poznań, pp. 139-150, 2 tables, 5 figs. DOI 10.2478/quageo-2014-0022, ISSN 0137-477X.

ABSTRACT: The delimitation of nodal regions belongs among the fundamental methods of studying spatial organisation. Nodal regions are defined as regions in which intraregional interactions are closed. With respect to the available information on spatial interactions, nodal regions are defined especially on the basis of data on commuting to work, migration flows, etc. Much less attention, however, has been paid to the theoretical and methodological questions of delimitation of nodal regions based on transport flows. In this case, transport flows that rank among the bearers of basic spatial interactions have high explanatory power, as they reflect not only commuting relations (commuting to work), but also service, business, recreational and other relations. The goal of this paper is to delimit nodal regions based on car transport flows in two regions in the Czech Republic and to evaluate their relevance in studying complex socio-economic relations within the regions.

KEY WORDS: nodal regions, road transport, regionalisation, Czech Republic

Stanislav Kraft (corresponding author), Dagmar Popjaková, Department of Geography, University of South Bohemia in České Budějovice, Jeronýmova street No. 10, 37115 České Budějovice, Czech Republic; e-mail: kraft@pf.jcu.cz, dpopjakova@pf.jcu.cz Miroslav Marada, Department of Social Geography and Regional Development, Charles University in Prague, Albertov street No.6, 12843 Praha, Czech Republic; e-mail: marada@natur.cuni.cz

\section{Introduction}

Car transport is one of the most developed transport modes in the Czech Republic. Especially after 1989 in connection with the fall of the totalitarian regime, this mode has achieved extraordinary dynamic development, as reflected in its significant dominance on the passenger transport market since the 1990s. An increase in the use of passenger cars to a level similar to that in advanced countries, therefore, became one of the basic attributes of the Czech society's transformation in the post-totalitarian period. Geographically, it is important that the increase in the passenger car intensity did not follow a uniform trend throughout the country, but was of a significantly selective nature. An interesting feature in the changes of the spatial distribution of car transport intensities is a distinctive focus on creating an apparent nodal structure of the transport system, together with main interconnecting transport axes. Besides an increase in intensity on main roads, the growth rate of passenger car intensities after 1989 was most prominent in urban and suburban areas. Thereby transport contacts between centres and their hinterlands became stronger than before. Hence, it is beyond dispute that transport flows primarily tend to form nodal 
transport relations between the centres and their hinterlands, and, therefore, have a great potential as an indicator for the delimitation of nodal transport regions (Jordan 1995). Transport relations also belong among the basic forms of spatial interactions and, therefore, have high social relevance and explanatory power (Rodrigue et al. 2009, Klapka et al. 2010).

Generally, a region is one of the basic concepts used in geography and is understood as a product of spatial differentiation of a geographical area. Regions are perceived as the most logical method of organisation of geographical information about a territory (Domański 1982). Human geography especially uses nodal regions, the fundamental principle of which is the existence of functional relations between the regional centre and its hinterland. Regions of this type are thus very important in human geography and have been addressed for a long time (Christaller 1933; Haggett 2001, etc.). Typical nodal regions are especially those of commuting to work, migration regions, catchment regions of service facilities, etc. Various characteristics are used for their delimitation, especially with respect to accessibility and the explanatory power of relation indicators. Similar procedures can be observed even with regions defined on the basis of transport data, except that less attention has been focused on them. Transport relations encompass not only commuting relations but also other relations, for example commuting to obtain various types of services, including business, recreational and other relations (Kunc et al. 2012). They can be considered bearers that provide information on complex socio-economic relations in the territory.

The general goal of this study - delimitation of nodal regions based on car transport flows is demonstrated in two NUTS 3 regions of the Czech Republic, namely the South Bohemian Region and the Moravian-Silesian Region, that show clear differences in their settlement structure characteristics, economic specialisation, degree of motorisation, etc. A specific goal is to address some methodological and application issues of transport-geographical regionalisation on which considerable attention was focused especially in the 1960s and 1970s. The paper also tackles significant questions of the general study of transport geography, namely relations between the transport and the settlement system as well as the relation between nodal transport regions and other types of nodal regions.

The next chapter outlines main theoretical and methodological concepts that concern nodal regions and their application in transport geography. The third deals with the methodological aspects of delimitation of nodal transport regions and the description of the data used. The fourth defines transport regions upon nodal relations that are then compared with other types of regionalisation of the study area. The last chapter summarises the findings and recommendations for the next research in transport regions.

\section{Nodal regions: Basic concepts and their applications in transport geography}

The concept of a nodal region is based on the assumption that a geographical area is heterogeneous. This heterogeneity, so typical especially of the human-geography sphere, leads to the formation of spatial interactions of various sizes. Nodal regions are, therefore, delimited upon the intensity of these interactions, generally between different parts of those regions and their one or more centres. It is just the centre and the hinterland that form an integral part of a nodal region. The centres of nodal regions are, as a rule, towns with a distinctive concentration of socio-economic activities to which their hinterlands are functionally integrated on the basis of the intensity of flows.

Taaffe et al. (1996) argue, however, that it is necessary to strictly distinguish between the field of catchment of a centre and its actual hinterland. The field of catchment is defined by all interactions between the centre and the surroundings, while the hinterland determines the catchment area of regional influence of one centre against the influence of another centre. The boundaries between nodal regions thus go through places where a radical change in the catchment orientation of units between two or more centres occurs. A division of an area into individual functionally closed regions is referred to as regionalisation.

The formation of nodal regions, according to Haggett (2001), is determined by six basic components: spatial interactions, networks, nodes, 
hierarchies, surfaces, and diffusion. This results in the real image of spatial differentiation of the socio-economic sphere in the area. The delimited regions thus have a variety of practical applications. They are frequently used to design and review an administrative division or to generally classify spatial relations and information on the spatial organisation of socio-economic activities (Halás et al. 2010).

An essential methodological question in nodal region delimitation, however, is accessibility and quality of relation indicators and indicators appropriate for the selection of individual autonomous centres (nodes). Karlsson and Olsson (2006) note that nodal regions are delimited mainly by labour market data. According to these authors, region delimitation therefore focuses on the delimitation of local labour market areas, commuting zones, or regions of accessibility based on potential interactions (Halás, Klapka 2010 or Kraft, Blažek 2012). There are many examples of delimitation of nodal regions based on commuting relations and total regionalisation of a territory (cf. e.g. Berry 1973; for information on the Czech and Slovak environment, see e.g. Bezák 2000, Hampl 2005, or Sýkora, Mulíček 2009). On a number of occasions, nodal commuting regions are deemed to be complex socio-geographic regions that are formed on the basis of interactions between a regional centre and its hinterland, and are integrated by means of this key region-making process (Hampl et al. 1987).

From the methodological viewpoint, two methods can be applied in delimitating nodal regions. The one more frequently used is a socalled deductive (top-down) method where the centres of regions are identified in the first step according to pre-determined criteria. At the second stage, these centres are allocated subordinate units based on a selected indicator in order to find the boundary between the spheres of influence of two centres. The third step is the delimitation of regions or, where relevant, a correction of pre-determined centres by the results of the regionalisation procedure (see e.g. Hampl 2005). It is the pre-determined centres and minimum sizes of regions that are most frequently criticised in the deductive regionalisation procedures used. The second approach to the delimitation of nodal regions employs an inductive (bottom-up) method that differs especially in the sequence of individual steps. At the first stage, the strongest interactions in a system and mutual clusters of relatively autonomous units are identified first, and regional centres are delimited on the basis of regionalisation procedure results at the last stage. An inductive method of regionalisation based on commuting interactions was applied by Coombes and Openshaw (1982), for instance. It is clear that, given their time consumption, inductive procedures are used rather rarely for the regionalisation of a territory. As a rule, the outcome of the inductive method applied to regionalisation is the delimitation of a higher number of regions that better reflect the degree of autonomy of smaller regions (weaker centres), reducing the regional sphere of activity of bigger centres (Karlsson, Olsson 2006).

Given the unique nature of transport relations, it is logical that the nodal region concept was frequently used in transport geography. Here, transport relations serve as key indicators for delimiting the regional sphere of activity of individual centres. In the approaches known so far, two types of study can be observed. First, it is studies of a predominantly methodological character which address the question of the delimitation of transport-oriented nodal regions. They deal especially with the questions of the nature and spatial patterns of transport relations as a key element of spatial organisation (Godlund 1956, Green 1958; for information on the Czech and Slovak environment, see Hůrský 1978, Branický 1988, Seidenglanz 2010, etc.). Also studies dealing with the application of graph theory to delimiting centres and their hinterlands (such as Nystuen, Dacey 1961 or Grubesic et al. 2009) are interesting. To delimit nodal regions, the authors especially use an origin-destination matrix built on the frequency of public transport links. The second group may be referred to as application studies. Those are primarily geared towards the use of transport regionalisation as a basis for a review and formation of a territorial and administrative subdivision, or where appropriate, towards the comparison of transport regions and other types of territory regionalisation (Jordan 1995, Kraft 2007). Other interesting studies include those evaluating associations between commuting regions and the regions of transport 
(time) accessibility (Hudeček 2008). It is clear that the above two thematic areas of research on transport regions do not exclude but complement each other.

\section{Data and methods}

The basic input on road transport intensity monitored on roads and motorways in the Czech Republic is data from the nationwide road transport census (RTC). It only comprises records of the average number of passenger cars driving in both directions of a surveyed stretch in 24 hours. In 2010, passenger car intensity was monitored on 7,686 stretches, i.e. on all motorways, speedways, 1st- and 2nd-class roads as well as a selected part of 3rd-class roads. The extent of the transport census makes it clear that this is a unique source of information on passenger and freight road transport intensity, which additionally provides sufficient details about the given territories. The drawbacks of these data are especially the impossibility of separating transit from local/microregional transport flows, as well as the absence of information on the occupancy of vehicles and impossibility of finding the starting and end points of individual journeys (Viturka 1981). Only passenger car data were included in the analysis as the most relevant for delimiting nodal relations at the microregional level.

The creation of a unique method for delimiting nodal regions based on transport intensity was inspired especially by Hůrský $(1974,1978)$, who was the first to delimit regions upon car transport intensity in former Czechoslovakia. In defining regions, he applied what is known as the saddle method: he identified saddle points (i.e. stretches with the lowest transport intensity) in the road network between two centres in which the fixing points of individual dividing lines were identified upon the extrapolation of counter-flows. Dividing lines delimited the hinterlands of the centres in terms of transport flow intensity. Hůrský, however, arrived at the conclusion that the RTC data had certain restrictions for regionalisation, e.g. a small density of survey stations and a low number of fixing points, and especially that its processing for regionalisation was very time-consuming. The last restriction is largely eliminated by using digitalised data and GIS. A similar method was also used by Jordan (1995) for the delimitation of catchment areas of macro- and mesoregional centres in East-Central Europe on the basis of bus traffic.

Since the initial and terminal points of individual journeys cannot be found in the database used, the regionalisation procedure derived from Hůrskýs method, which is close to the inductive regionalisation method, had to be applied in this study. The regionalisation itself was, therefore, conducted in four steps:

1. Identification of road-network saddle points. This identification consisted in searching for road stretches with car transport intensity lower than that in the neighbouring stretches.

2. Identification of fixing points of the dividing line (boundary between transport regions). The fixing point was found in the stretch with the minimum transport intensity by extrapolating counter-oriented catchments of transport intensity from neighbouring stretches.

3. Interconnection of fixing points using the dividing line. Fixing points on the closest roads were always connected. Dividing lines, therefore, close the strongest transport relations at the microregional level. Municipalities without any fixing point in their area were allocated on the basis of their time accessibility.

4. Identification of centres of transport regions. The nodes of convergence of stretches of roads with a higher transport intensity than that of the follow-up (saddle) stretches, i.e. towns delimited by the dividing line, became the centres of transport regions.

The advantage of the regionalisation procedure used is the fact that transport region centres were determined ex-post, i.e. inductively, after the regionalisation was made. In Hưrský (1978), a selection of transport centres in the first step was the main reason why he could not delimit transport regions on the basis of the road transport census. On the other hand, a certain risk of the selected method lies in the potential impact by higher transit transport intensity on main roads and in the identification of regions and centres of various hierarchical levels at the same time. It is, therefore, difficult to determine the hierarchy of individual centres and regions. This method, however, enables a real separation of transit 


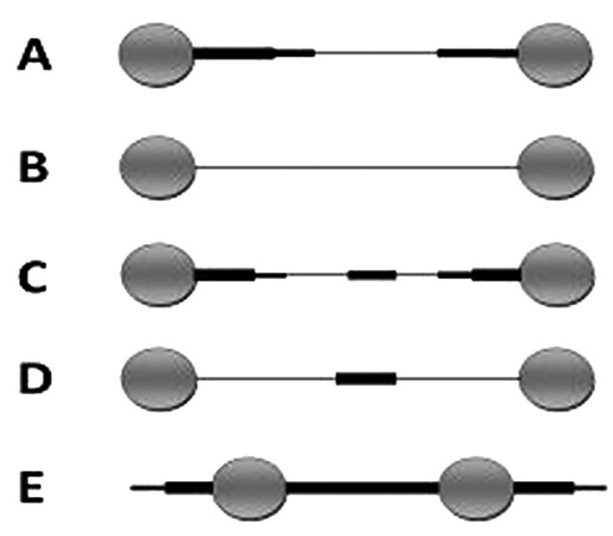

Fig. 1. Basic types of saddle stretch formation

transport from the transport responsible for main interactions between the centres and their hinterlands. The delimited nodal transport regions are thus a useful tool for evaluating and optimising the regional transport policy.

In the selected method, nodal transport regions were defined on the basis of average passenger car transport intensities. In respect of the application of reverse order of individual steps in regionalisation, a total of five types of saddle stretch formation were defined (Fig. 1).

Type A was the most common one $(74 \%$ of saddles in the South Bohemian Region and 68\% in the Moravian-Silesian Region) where 'natural' saddles formed between two transport nodes. Type B, with the centres characterised by the same transport intensity and located as a rule in the peripheral zone, occurred in a few cases. The fixing point of the dividing line, therefore, lay in the middle of the given stretch. The isolated types $\mathrm{C}$ and $\mathrm{D}$ denote places where more saddles formed on the stretches, but there was no centre located on an interjacent stretch. In this case, the fixing point was delimited in a similar way as with type B. The situation when high transport intensity was observed between two centres without any reduction (type E) occurred in two cases only. In this case, the existence of a two-centre region was established.

\section{Transport regions - an example of the South Bohemian Region and the Moravian-Silesian Region}

Transport intensity in the Czech Republic is significantly affected by the regional settlement system configuration. Long-term trends in the development of the settlement system were significantly influenced by artificial interventions during the totalitarian period, for example the introduction in the 1960s and 1970s of a central settlement system that artificially supported settlement centres at intermediate hierarchical levels. The post-totalitarian stage of the settlement system development saw the restart of natural development trends leading to the promotion of bigger centres (suburbanisation, metropolitanisation) and, on the other hand, to a reduction in the importance of microregional centres. In this period, some smaller, formerly autonomous, centres were reduced. Despite this trend, the current settlement system of the Czech Republic can be classified as fragmented, but stabilised. Microregional centres, of course, play a relatively important role in the daily movement of inhabitants, which is logically represented in the spatial distribution of transport flows again.

The South Bohemian Region is one with the lowest population density in the Czech Republic (63 inhabitants per square $\mathrm{km}$ ). Its settlement system is characterised by the existence of numerous less populated localities and an apparent, relatively regular network of lesser centres representing concentration points of inhabitants and economic activities. České Budějovice with its population of nearly 100,000 represents a natural regional metropolis that attracts especially the central and southern parts of the South Bohemian Region in terms of commuting (Vančura 2005). With such a settlement structure and a lower density of public transport networks, the South Bohemian Region ranks among regions at a very high level of individual motorisation, with 45.2 passenger cars per 100 inhabitants of the region. A totally different structure is typical of the Moravian-Silesian Region. With its very strong industrialisation, the region has the second highest population density (261 inhabitants per square kilometre). The population distribution within the region is very un- 


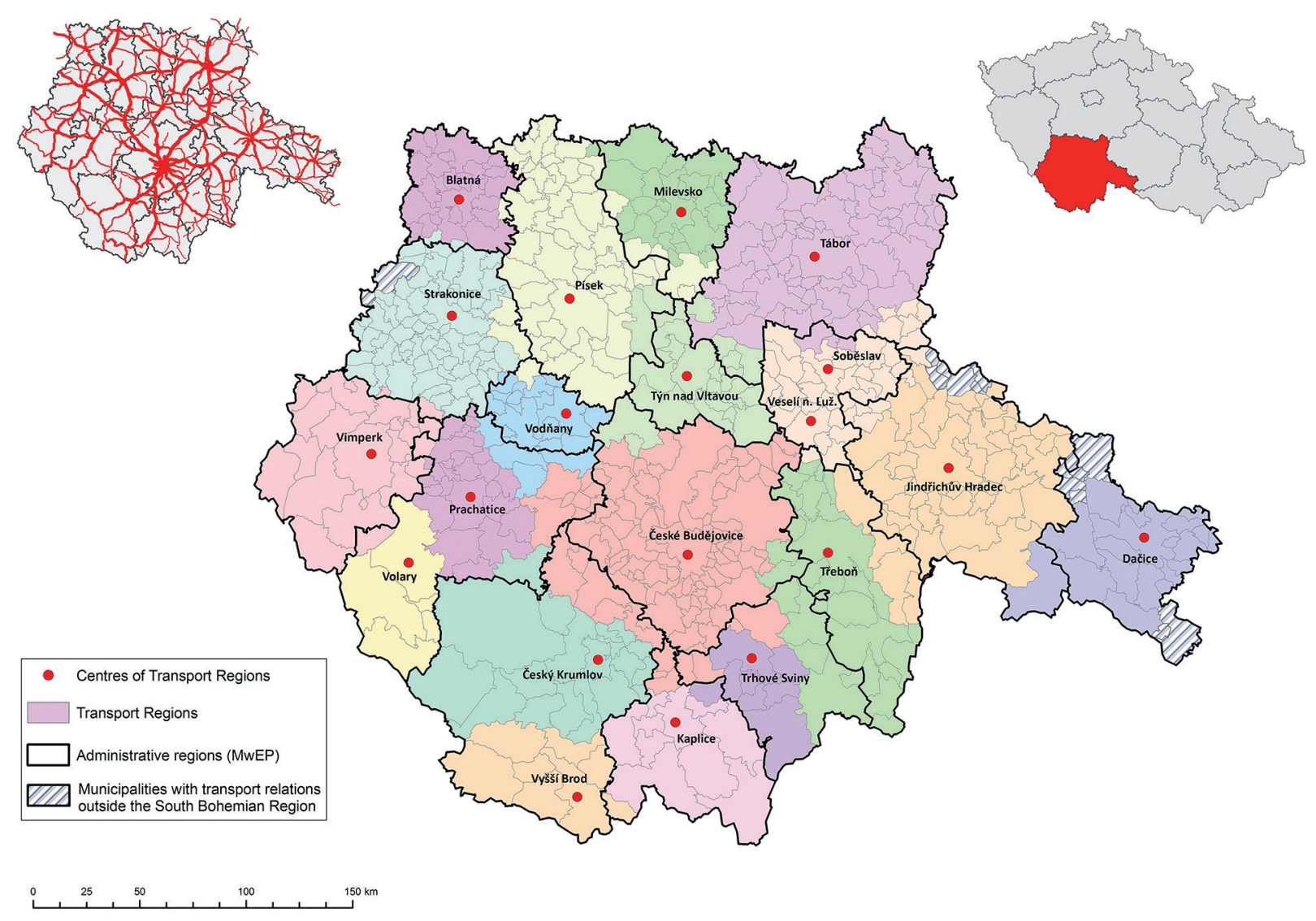

Fig. 2. Transport regionalisation of the South Bohemian Region (2010) Source: RTC 2010, own calculations

even, with the highest values in the conurbation around the regional metropolis of Ostrava and, on the other hand, sparsely populated mountain ranges in the west and east. Its settlement structure includes big cities, and there is a low number of people living in localities with less than 500 inhabitants. There are only 36.0 passenger cars per 100 inhabitants, which is the lowest value in the Czech Republic. The low level of motorisation is largely due to a relatively dense network of public transport services, including intensive railway transport.

Using the selected method, transport regions were delimited in the study area on the basis of car transport intensity. The delimited regions reflect the regional sphere of activity of individual centres of transport regions at the microregional level. They represent the fundamental cornerstones of the regional structure of regional transport systems. Since the saddle method was applied, relatively closed transport relations be- tween the centres and their hinterlands can be expected within these nodal regions.

A total of 19 transport regions were delimited in the South Bohemian Region. Given the specific features of its settlement system, it is apparent that especially microregional centres, the importance of which is further supported by the present position within the administrative structure, have become their centres. All transport centres are also administrative centres of municipalities with extended powers (MwEP). The exception is the less populated centres of Volary and Vyšši Brod in the border zone, the transport importance of which is supported by their relative remoteness from bigger centres. The size of transport regions is strongly associated with the population of individual centres. As far as the number of integrated municipalities is concerned, the transport region of České Budějovice is the most important one, as $15.4 \%$ of all municipalities in the region and more than $26 \%$ of its inhabitants are integrated to it. On the other hand, the lowest 


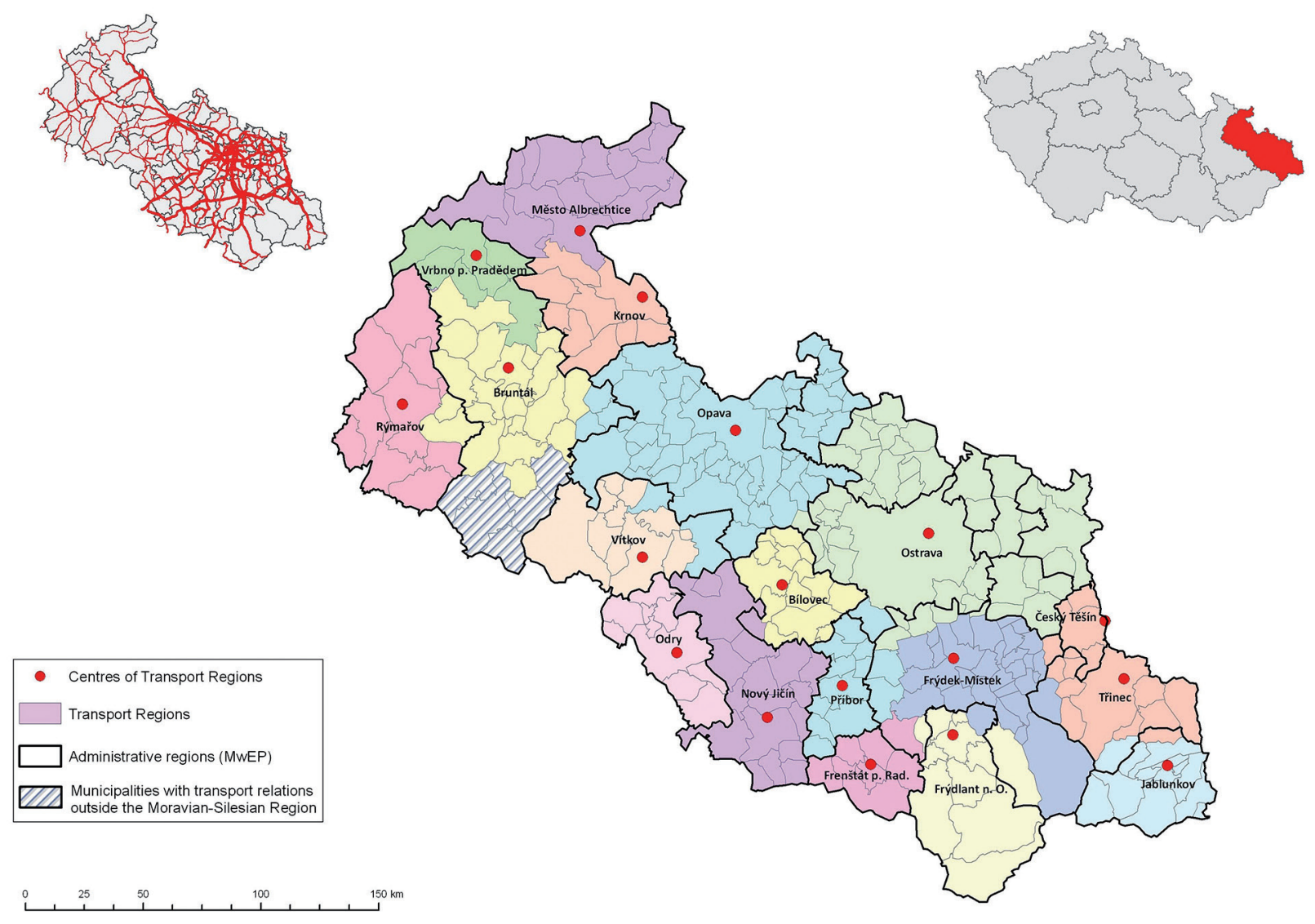

Fig. 3. Transport regionalisation of the Moravian-Silesian Region (2010) Source: RTC 2010, own calculations

number of subordinate municipalities from the transport perspective is typical of the lesser centres which are, moreover, located in the border zone. Their transport sphere of activity is often limited by the low density of road networks.

A total of 17 transport regions were delimited in the Moravian-Silesian Region. A salient feature is that they are concentrated in its highly industrialised parts characterised by a number of more populous towns. The specific structure of the settlement system with big settlement centres not far from each other leads to the notable fragmentation of transport flows. Saddles of transport intensities between those centres form very often and determine frequent formation of transport regions. Another salient feature is the restriction of the regional sphere of activity of bigger settlement centres, which arises out of the transport flow fragmentation and the more frequent formation of saddles in transport intensity (evident here is the drawback of the inductive method, i.e. undistinguished hierarchical lev- els of centres). From the viewpoint of transport flow, the regional sphere of activity of Ostrava is thus limited to 48 municipalities only $(12.7 \%$ of municipalities, but representing $52.1 \%$ of the region's population).

Another interesting piece of knowledge coming from the transport regionalisation of the two regions under analysis is a distinctive connection between the delimited transport regions and the administrative division. Transport regions are strongly associated with the administrative districts of municipalities with extended powers (MwEP). More distinctive discrepancies between the administrative and transport divisions can be noted in larger and rarely populated regions (Český Krumlov, Prachatice) and in those with a low road network density where the transport catchment is affected by the configuration of roads. In the Moravian-Silesian Region, there is a notable mismatch between both types of regions, especially in the densely populated Ostrava conurbation divided into a total of six administra- 
Table 1. Basic size characteristics of the South Bohemian Region and the Moravian-Silesian Region

\begin{tabular}{|l|c|r|r|c|c|r|c|}
\hline \multicolumn{1}{|c|}{ Region } & $\begin{array}{c}\text { Integrated } \\
\text { municipalities }\end{array}$ & Population & Area & Region & $\begin{array}{c}\text { Integrated } \\
\text { municipalities }\end{array}$ & Population & Area \\
\hline České Budějovice & 96 & 165,411 & 1162.5 & Ostrava & 48 & 641,567 & 838.1 \\
\hline Tábor & 70 & 79,797 & 919.8 & Opava & 53 & 124,825 & 740.0 \\
\hline Písek & 55 & 53,979 & 808.5 & Frýdek-Místek & 28 & 91,932 & 357.4 \\
\hline $\begin{array}{l}\text { Jindřichův Hra- } \\
\text { dec }\end{array}$ & 47 & 48,753 & 910.9 & Třinec & 14 & 84,427 & 263.0 \\
\hline Strakonice & 64 & 41,577 & 505.2 & Nový Jič́n & 17 & 53,28 & 335.4 \\
\hline Český Krumlov & 19 & 28,47 & 719.3 & Př́bor & 13 & 48,13 & 177.2 \\
\hline Třeboň & 27 & 26,86 & 607.5 & Krnov & 9 & 31,548 & 207.8 \\
\hline Soběslav & 43 & 22,87 & 400.9 & Bruntál & 21 & 31,337 & 387.2 \\
\hline Prachatice & 26 & 19,445 & 331.0 & B́́lovec & 12 & 26,16 & 163.1 \\
\hline Vimperk & 24 & 19,266 & 574.4 & Frenštát p. R. & 8 & 23,595 & 139.9 \\
\hline Dačice & 18 & 17,276 & 442.1 & Jablunkov & 12 & 21,162 & 183.3 \\
\hline Milevsko & 22 & 17,242 & 318.1 & Frýdlant n. O. & 11 & 19,654 & 334.6 \\
\hline Týn n. Vltavou & 23 & 17,109 & 426.0 & Rýmařov & 10 & 13,749 & 331.9 \\
\hline Vodňany & 21 & 13,403 & 253.4 & Odry & 9 & 13,262 & 174.5 \\
\hline Blatná & 23 & 13,391 & 264.6 & Vítkov & 10 & 12,218 & 244.4 \\
\hline Kaplice & 10 & 13,193 & 427.6 & Albrechtice & 16 & 11,508 & 370.0 \\
\hline Trhové Sviny & 8 & 9,142 & 226.2 & Vrbno p. P. & 5 & 8,574 & 166.4 \\
\hline Vyšší Brod & 8 & 7,653 & 333.0 & & & & \\
\hline Volary & 5 & 5,041 & 290.4 & & & & \\
\hline
\end{tabular}

Source: RTC 2010, own calculations

tive regions, whilst it forms one compact unit in terms of transport. A greater distance between the centres and the lower number of localities here determine the more frequent formation of saddles and give rise to 'intermediate centres' (such as Albrechtice, Vrbno pod Pradědem). This phenomenon has already been confirmed in former studies (e.g. Godlund 1956).

\section{Relation between transport regions and commuting regions}

To prove an objective existence and relevance of transport regions in studying complex socio-economic relations, it is important to analyse their connection with the regions of commuting to work. As already noted, commuting to work is deemed to be a key region-making process. With the data on commuting to work taken from many types of regionalisation in the Czech Republic, it is appropriate to compare the delimited transport regions with the commuting regions defined in Halás et al. (2010). This study defines a total of 271 nodal microregions in the Republic in terms of the commuting relations between the centres and their hinterlands. For comparative purposes, this regionalisation is appropriate especially due to the delimitation of commuting regions at the lowest hierarchical level. These regions comply more with the principles of inductive methods of regionalisation. They reflect interactions of centres with their nearest hinterlands and are thus appropriate for comparison with transport regions.

A comparison of the final number of regions is especially interesting as different trends in region formation can be observed in both regions with respect to their specific socio-economic conditions. While a total of 17 administrative regions are currently delimited in the South Bohemian Region, the results of transport regionalisation show that there are a total of 19 transport regions there. Halás et al. (2010) even identified 22 com-

Table 2. Number of delimited regions in the South Bohemian and Moravian-Silesian Regions

\begin{tabular}{|c|c|c|c|}
\hline & $\begin{array}{c}\text { Admin- } \\
\text { istrative } \\
\text { regions }\end{array}$ & $\begin{array}{c}\text { Transport } \\
\text { regions }\end{array}$ & $\begin{array}{c}\text { Commut- } \\
\text { ing regions }\end{array}$ \\
\hline $\begin{array}{c}\text { South Bohemian } \\
\text { Region }\end{array}$ & 17 & 19 & 22 \\
\hline $\begin{array}{c}\text { Moravian-Silesian } \\
\text { Region }\end{array}$ & 22 & 17 & 16 \\
\hline
\end{tabular}

Source: RTC 2010, own calculations, Halás et al. (2010) 


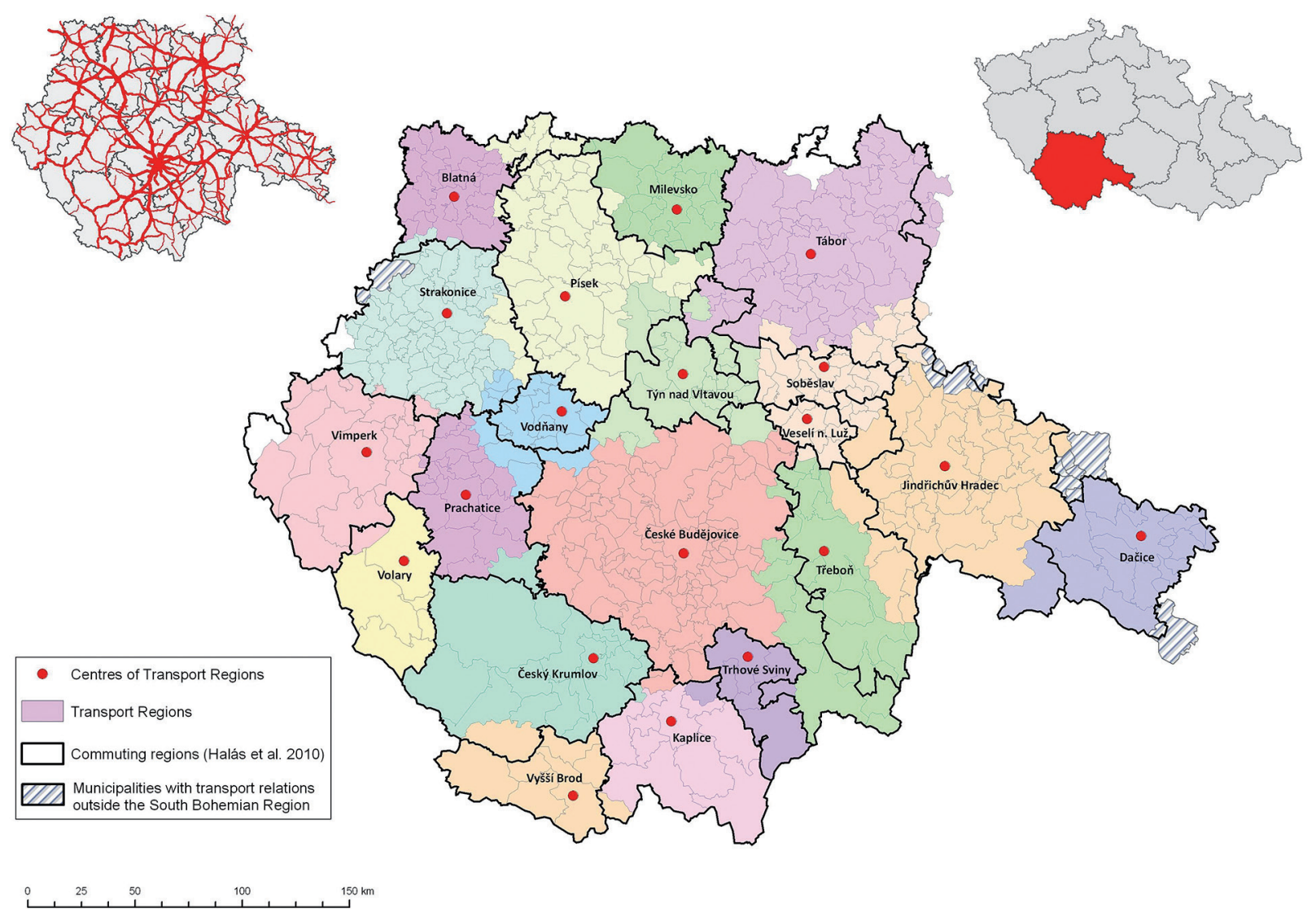

Fig. 4. Comparison of transport regionalisation and commuting regionalisation: South Bohemian Region Source: RTC 2010, Halás et al. (2010), own calculations

muting regions. It is clear that, unlike the administrative division, the particular local settlement structure contributes to the formation of certain intermediate centres that play a role of transport or commuting centres at the lower hierarchical level. This is especially exemplified by the border centre of Vyšší Brod that unquestionably forms a transport, or a commuting, region. In the Moravian-Silesian Region, on the other hand, there are a total of 22 administrative regions at present, while its nodal regions have only 17 transport centres and 16 commuting centres around them. The administrative division in this region is thus adapted to the principle of catchment regions of relatively the same population numbers, while transport and commuting relations better reflect the exposure of centres and natural relations with their hinterlands.

A comparison of transport and commuting regions is shown in Figs 4 and 5. In both regions it is possible to identify even more distinctive matches between transport regionalisation and commuting regionalisation. It is clear that both transport and commuting relations are closed in most of the delimited transport regions. Differences in the delimitation of both types of regions can be considered relatively minor. In the South Bohemian Region this concerns especially the pertinence of municipalities to the centres on the boundaries of individual regions. The differences here are primarily caused by the application of an additional time-accessibility criterion, which determines the catchments of municipalities not intersected by any road included in the RTC system in 2010. A distinctive match between both types of regions is also apparent in the Moravian-Silesian Region. It is, however, difficult to determine the degree of autonomy of individual regions here. Some centres (Bílovec, Jablunkov) along with their transport catchment regions form autonomous areas whilst clearly subordinate to bigger centres in terms of commuting (a similar phenomenon was observed by Karlsson and Olsson 2006). The situation is different in Karviná, which 


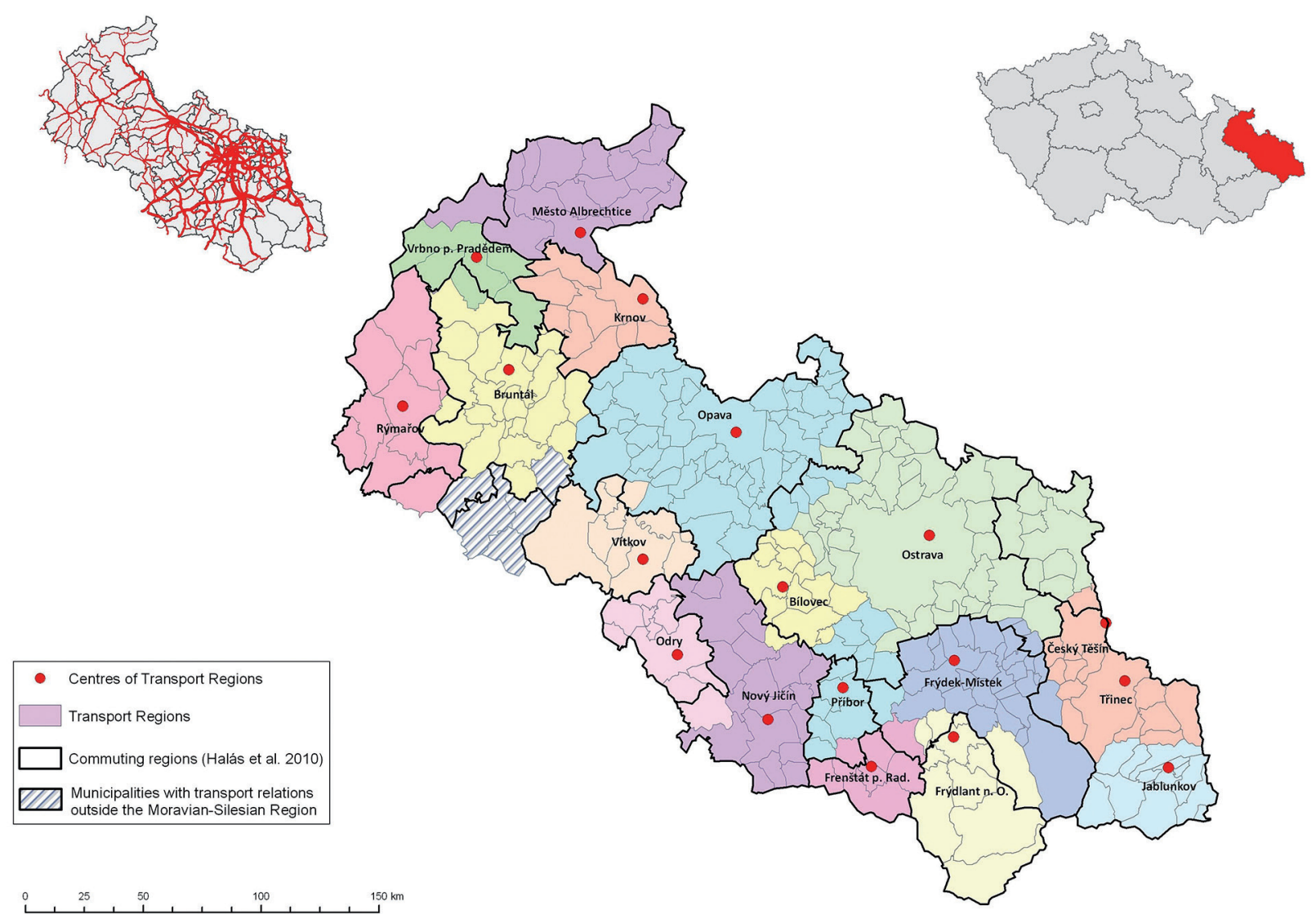

Fig. 5. Comparison of transport regionalisation and commuting regionalisation: Moravian-Silesian Region Source: RTC 2010, Halás et al. (2010), own calculations

forms an autonomous commuting region, but it is unambiguously integrated to Ostrava in terms of transport. It is, however, necessary to note that especially the area of the Ostrava conurbation is perceived differently in individual types of regionalisation. As a result, its clear delimitation is, to a certain degree, subjective.

\section{Conclusions}

This paper was mainly intended to delimit nodal regions based on the intensity of car transport in two model regions of the Czech Republic in order to assess the relevance of socio-geographic regionalisation upon transport data. The results obtained entail a variety of interesting findings that can be used in generalising conclusions concerning transport and geographical regionalisation. They can be summed up in the following points:
1. The applied method has proved that the intensity of motorised private transport can be used as a suitable criterion in delimiting socio-geographic regions. The delimited transport regions are spatially compact and logically structured; they close main transport routes between the centres and their hinterlands in them, thus maximising their internal integrity with the surroundings. By using an inductive method of regionalisation we have avoided pre-defining 'a right number' of transport region centres, which was the main reason for the failure of previous attempts by Hưrský (1978) to define transport regionalisation. However, a certain heterogeneity of the delimited regions, or more precisely, difficulties with specifying a hierarchy of their importance and the degree of autonomy in the system, still remains a problematic issue. This fact should be one of the main directions of further research on transport regions. 
2. Using the selected method, we delimited transport regions in two regions of the Czech Republic. They can be viewed as elementary final forms of spatial relations between the centres and their hinterlands, this time expressed in terms of transport flow intensity. Their formation is primarily determined by the settlement system configuration, or more precisely, by the transport network distribution. The transport intensity saddles that often determine the creation of transport regions are very frequently formed in densely populated areas. The regional sphere of activity of the biggest settlement centres is thus restricted and shattered in the transport perspective. On the other hand, in less populated regions (near the borders), there is an apparent tendency towards the formation of 'intermediate centres' that fulfil transport functions for smaller and less populated transport regions (Blažek, Netrdová 2012). A low density of the road network, a low intensity of traffic or a relative remoteness from big settlement centres can be viewed as factors of secondary importance, which, however, manifest themselves rather selectively.

3. Transport regions can be considered to be relatively closed socio-geographic units concerning relations. This is demonstrated by their close connection with the administrative division and especially with regions of commuting to work and schools, deemed to be key territorial units in socio-geographic regionalisation. It is questionable to what degree commuting indicators fulfil the role of a representative of complex socio-economic relations in regions today. It can be envisaged that, given the dominant position of car transport on today's Czech transport market, its intensity, in principle, reflects the essential features of the operation of the regional system. In our opinion, transport regions can be deemed to be autonomous territorial units that provide explanatory power comparable to that of commuting regions.

\section{Acknowledgement}

The article was elaborated within the framework of the research grant project "Spatial Dynamics of Transport
Relationships in the Settlement System of the Czech Republic", reg. No. 404/12/1035 sponsored by the Czech Science Foundation.

\section{References}

Berry B.J.L., 1973. Growth centres in the American urban system. Ballinger, Cambridge, MA.

Bezák A., 2000. Funkčné mestské regiony na Slovensku (Functional urban regions in Slovakia). Geographia Slovaca 15, Bratislava.

Blažek J., Netrdová P., 2012. Aktuální tendence lokální diferenciace vybraných socioekonomických jevů v Česku: směřuje vývoj $\mathrm{k}$ větší mozaikovitosti prostorového uspořádání? (Contemporary tendencies in the development of selected socio-economic phenomena at the local level in Czechia: Towards greater fragmentation of the spatial pattern?). Geografie 117(3): 266-288.

Branický M., 1988. Regionálne členenie Slovenskej socialistickej republiky z hladiska dopravy (Regional division of the Slovak Socialist Republic from the transport point of view). In: Holeček M. (ed.), Současný stav a perspektivy dopravní geografie. Geografický Ústav ČSAV, Brno: 104-110.

Coombes M., Openshaw S., 1982. The use and definition of travel-to-work areas in Great Britain: some comments. Regional Studies 16(2): 141-149.

Christaller W., 1933. Die zentralen Orte in Süddeutschland. Gustav Fischer, Jena.

Domański R., 1982. Teoretyczne podstawy geografii ekonomicznej (Theoretical foundations of economic geography). Warszawa, PWN.

Godlund S., 1956. The function and growth of bus traffic within the sphere of urban influence. Lund, Series in Human Geography 18.

Green F., 1958. Community of interest areas. Notes on the hierarchy of central places and their hinterlands. Economic Geography 34(3): 210-226.

Grubesic T.H., Matisziw T.C., Zook M.A., 2009. Spatio-temporal fluctuations in the global airport hierarchies. Journal of Transport Geography 17(4): 264-275.

Haggett P., 2001. Geography: A global synthesis. Prentice Hall, London.

Halás M., Kladivo P., Šimáček P., Mintálová T., 2010. Delimitation of micro-regions in the Czech Republic by nodal relations. Moravian Geographical Reports 18(2): 16-22.

Halás M., Klapka P., 2010. Regionalizace Česka z hlediska modelování prostorových interakcí (Regional division of Czechia on the basis of spatial interaction modelling). Geografie 115(2): 144-160.

Hampl M., Gardavský V., Kühnl K., 1987. Regionální struktura a vývoj systému osídlení ČSR (Regional structure and development of the settlement system in Czechoslovakia). Univerzita Karlova, Praha.

Hampl M., 2005. Geografická organizace společnosti v České republice: Transformační procesy a jejich obecný kontext (Geographical organisation of society in the Czech Republic: Transformation processes and their general context). Univerzita Karlova v Praze, Praha.

Hudeček T., 2008. Model časové dostupnosti individuální automobilové dopravy (Model of temporal accessibility of individual car transport). Geografie 113(3): 140-153.

Hůrský J., 1974. K regionalizaci ČSR na základě výsledků sčítání silniční dopravy (Towards the regionalisation of 
Czechoslovakia on the basis of the results of road transport census). Doprava 16(3): 143-151.

Hůrský J., 1978. Regionalizace České socialistické republiky na základě spádu osobní hromadné dopravy (Regionalisation of the Czech Socialist Republic based on the gravity of public transport). Studia Geographica 59, Geografický Ústav ČSAV, Brno.

Jordan P., 1995. Functional regions in East-Central Europe defined on the basis of the frequency of public bus traffic. Geografický časopis 47(1): 9-15.

Karlsson C., Olsson M., 2006. The identification of functional regions: Theory, methods, and applications. Annals of Regional Science 40(1): 1-18.

Klapka P., Frantál B., Halás M., Kunc J., 2010. Spatial organisation: development, structure and approximation of geographical systems. Moravian Geographical Reports 18(3): 53-65.

Kraft S., 2007. Dopravně geografická regionalizace a hierarchie dopravních středisek Karlovarského kraje (Transport geographical regionalisation and the hierarchy of transport centres in the Karlovy Vary region). In: Kraft S. et al. (eds), Česká geografie v evropském prostoru. Sborník z XXI. sjezdu ČGS: 130-138.

Kraft S., Blažek J., 2012. Spatial interactions and regionalisation of the Vysočina Region using the gravity models. Acta Universitatis Palackianae Olomucensis, Facultas Rerum Naturalium, Geographica 43(2): 65-82.

Kunc J., Tonev P., Frantál B., Szczyrba Z., 2012. Nákupní spád, nákupní chování a nákupní centra: příklad brněn- ské aglomerace - příspěvek ke studiu denních urbánních systémů (Retail gravity models, shopping habits and shopping centres: the case of the Brno agglomeration - a contribution to the study of daily urban systems). Sociologický časopis 48(5): 879-910.

Nystuen J., Dacey M., 1961. A graph theory interpretation of nodal regions. Papers in Regional Science 7(1): 29-42.

Rodrigue J.P., Comtois C., Slack B., 2009. The geography of transport systems. Routledge, New York.

Seidenglanz D., 2010. Transport relations among settlement centres in the eastern part of the Czech Republic as a potential for polycentricity. Acta Universitatis Carolinae - Geographica, XLV (1): 75-89.

Sýkora L., Mulíček O., 2009. The micro-regional nature of functional urban areas (FUAs): lessons from the analysis of the Czech urban and regional system. Urban Research and Practice 2(3): 287-307.

Taaffe E.J., Gauthier H.L., O'Kelly M.E., 1996. Geography of transportation. Prentice Hall, Upper Saddle River, NJ.

Vančura M., 2005. Foreign direct investment in the countries of Central Europe with the emphasis on the Czech Republic. In: Michalski T. (ed.), Geographical aspects of transformation process in Central and East-Central Europe. Wydawnictwo Bernardinum, Pelplin.

Viturka M., 1981. Vztah sídelní struktury a silniční dopravy (The relation between settlement structure and road transport). Sborník Československé geografické společnosti 86(1): 28-37. 